\title{
INTENTIONAL HUMAN-CAUSED MORTALITY OF PLESTIODON COPEI (SCINCIDAE).
}

\section{MORTALIDAD INTENCIONAL DE PLESTIODON COPEI(SCINCIDAE) CAUSADA POR HUMANOS.}

\author{
J. Carlos Alvarado-Avilés ${ }^{1}$, Javier Manjarrez ${ }^{2}$ and Hermilo SÁnCheZ-SÁnchez ${ }^{* 2}$ \\ ${ }^{1}$ Facultad de Ciencias, Universidad Autónoma del Estado de México, Instituto Literario 100, Toluca Centro, Estado de México, México, C.P. 50200. \\ ${ }^{2}$ Centro de Investigación en Recursos Bióticos, Universidad Autónoma del Estado de México, Instituto Literario 10o, Toluca Centro, Estado de México, \\ México, C.P. 50200. \\ "Correspondent:hss@uaemex.mx
}

Abstract.- In México, several species of lizards are popularly considered as venomous species because they have bright colors, therefore they are susceptible to being intentionally killed. In this note we report an intentional mortality of a gravid female of Plestiodon copei for being considered as a venomous lizard, mainly for its tail coloration. This type of activity has a negative impact on the populations of P. copei, therefore it is necessary to highlight to the local residents that it is not a venomous species.

Keywords.- Agricultural area, deliberated killing, illegal hunting, non-venomous lizard.

Resumen.- En México diversas especies de lagartijas son popularmente consideradas como especies venenosas por poseer colores brillantes por lo que son suceptibles a ser asesinadas intencionalmente. En esta nota reportamos una muerte intencional de una hembra grávida de Plestiodon copei por ser considerada como una lagartija venenosa, principalmente por su coloración caudal. Este tipo de actividades repercute negativamente en las poblaciones de P. copei por lo que es necesario enfatizar a los pobladores locales que es una especie no venenosa.

Palabras clave.- Área agrícola, muerte deliberada, caza ilegal, lagatija no venenosa.

In several Mexican states, such as Nayarit, Jalisco, Colima, Michoacán and Estado de México, many people believe that a number of species of lizards are venomous because they are brightly colored or have an otherwise unusual appearance. People often think that a single bite from these species can kill humans and other animals, and they usually get scared and walk away from them or kill them immediately. Examples of lizards some people think are venomous include Barisia imbricata, Sceloporus grammicus, S. torquatus (Manjarrez, 1999), Phyllodactylus lanei, Hemidactylus frenatus (Casas-Andreu, 2000), Abronia taeniata, Phrynosoma orbiculare, and Plestiodon lynxe (Penguilly et al., 2010).

On the first of May 2015 we found an adult female Plestiodon copei $(\mathrm{SVL}=5.56 \mathrm{~cm})$ that had recently been killed in an agricultural area by a local resident of Amanalco de Becerra,

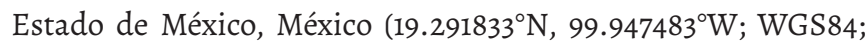
$2877 \mathrm{~m}$ a.s.l.). We found two serious injuries that probably killed the female. One was in the head and the other middle body (Fig. IA). Additionally, during necropsy we discovered three well developed embryos (Fig. 1B). Both injuries were caused when a person deliberately hit the lizard with a stick. There are two main reasons for intentional resident-caused mortality of $P$. copei (Fig. 2) in Amanalco de Becerra. They believe that; 1) skink lizards are small venomous snakes due to their mechanism of locomotion, reduced limbs and bright blue tail color, and 2) a bite of $P$. copei on the limbs of horses and farm animals can kill them. To our knowledge this is the first documented instance of $P$. copei killed because a human considered it to be venomous. This incident may lead to a severe population decline of P. copei. A short-term strategy to reverse this situation is to educate the local population and highlight the fact that P. copei is not a venomous lizard. 


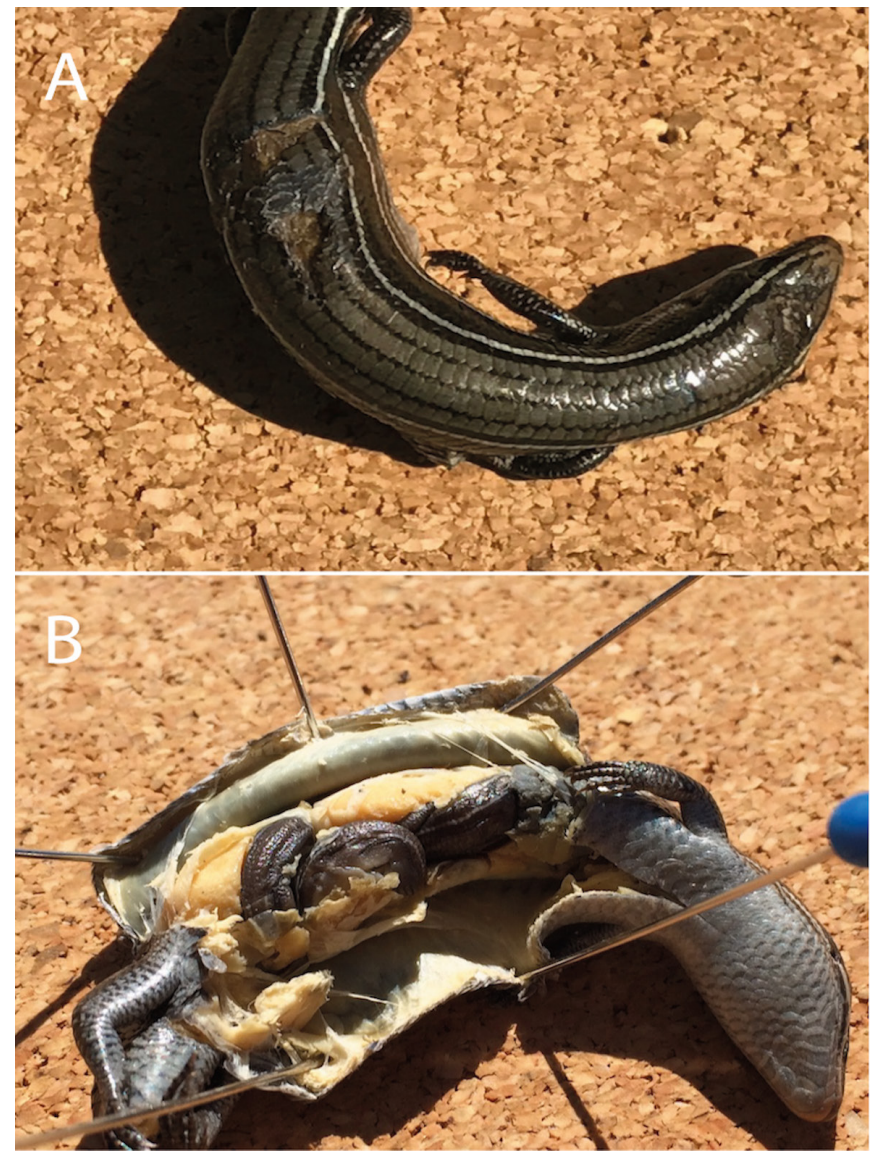

\section{CITED LITERATURE}

Manjarrez, S.J. 1999. Diversidad, problemática y perspectivas de los anfibios y reptiles del Estado de México. Cultus 1(2):45-51.

Casas-Andreu, G. 2000. Mitos, leyendas y realidades de los reptiles en México. Ciencia Ergo Sum 7(3):286-291.

Penguilly, M.M.A., F.A. Moreno., I.G. Mayer-Goyenechea \& G. Espinoza. 2010. Percepción acerca de las lagartijas consideradas nocivas por algunos otomíes, nahuas, tepehuas y mestizos en el estado de Hidalgo, México. Pp. 99-105. En F.A. Moreno, S.M.T. Pulido, M.R. Mariaca, A.R. Valadez, C.P. Mejía y T.V. Gutiérrez (Eds.). Sistemas biocognitivos tradicionales, paradigmas en la conservación biológica y el fortalecimiento cultural. Asociación Etnobiólogica Mexicana A.C., Global Diversity Foundation, Universidad Autónoma del Estado de Hidalgo, El Colegio de la Frontera Sur y Sociedad Latinoamericana de Etnobiología, México.

Figure 1. A) Dead female Plestiodon copei with cephalic and middle body injuries. B) Three well-developed embryos of $P$. copei found inside body cavity of the dead female.

Figura 1. A) Hembra muerta de Plestiodon copei con heridas en la cabeza y en la mitad del cuerpo. B) Tres embriones bien desarrollados dentro de la cavidad de la hembra muerta de P. copei.

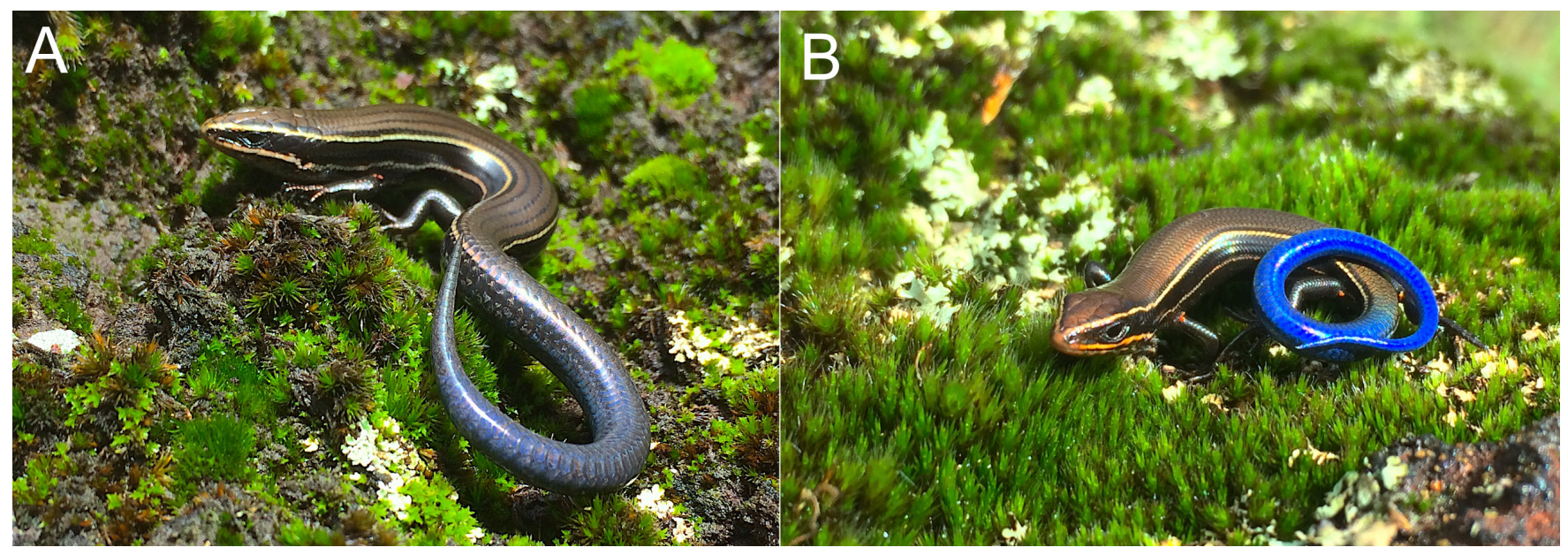

Figure 2. A) Adult and B) neonate males of Plestiodon copei with the distinctive bright blue tail color..

Figura 2. A) Adulto and B) macho neonato de Plestiodon copei mostrando la distintiva cola azul brillante. 